\title{
An HBV-HIV Co-infected Patient Treated with Tenofovir-based Therapy who Achieved HBs Antigen/Antibody Seroconversion
}

\author{
Takao Watanabe ${ }^{1}$, Yoshio Tokumoto ${ }^{1}$, Masashi Hirooka ${ }^{1}$, Yohei Koizumi ${ }^{1}$, Fujimasa Tada ${ }^{1}$, \\ Hironori Ochi ${ }^{1}$, Masanori Abe ${ }^{1}$, Teru Kumagi ${ }^{1}$, Yoshio Ikeda ${ }^{1}$, \\ Bunzo Matsuura ${ }^{1}$, Kiyonori Takada ${ }^{2}$ and Yoichi Hiasa ${ }^{1}$
}

\begin{abstract}
The present report describes a case of a patient with hepatitis B virus (HBV)-human immunodeficiency virus (HIV) co-infection who was treated with tenofovir disoproxil (TDF)-based highly active antiretroviral therapy (HAART) and who achieved HBs antigen (Ag)/antibody (Ab) seroconversion. An 18-year-old Japanese man with HIV and HBV co-infection presented to our hospital. His CD4 count was decreased, and TDF-based HARRT was started. At 30 months after initiation of therapy, HBsAg was not detected. At 36 months after initiation of therapy, HBsAb was detected. We conclude that TDF-based therapy is useful for the management of patients with HBV and HIV co-infection.
\end{abstract}

Key words: hepatitis B virus, human immunodeficiency virus, co-infection, tenofovir, seroconversion

(Intern Med 53: 1343-1346, 2014)

(DOI: 10.2169/internalmedicine.53.2131)

\section{Introduction}

Worldwide, 40 million patients are infected with the human immunodeficiency virus (HIV), and because of similar routes of transmission, $10-15 \%$ concomitantly suffer from chronic hepatitis B virus (HBV) infection (1). Liver-related mortality is one of the most common causes of non-acquired immunodeficiency syndrome (AIDS)-related death in the HIV-infected population (2). Compared with monoinfection, the course of a chronic HBV infection is more aggressive, and individuals with HIV co-infection tend to have a higher prevalence of cirrhosis (3). Therefore, management and treatment of HBV co-infection in patients with HIV is of great clinical importance to prevent the progression towards end-stage cirrhosis and hepatocellular carcinoma. Tenofovir disoproxil (TDF) is a nucleotide reverse transcriptase inhibitor that is active against HIV. It is recommended as part of the nucleotide reverse transcriptase inhibitor (NRTI) back- bone in combination with a non-nucleotide reverse transcriptase inhibitor (NNRTI) or a protease inhibitor (PI) as firstline highly active antiretroviral therapy (HAART) $(2,4,5)$. The present report describes a case of a patient with HBVHIV co-infection who was treated with TDF-based HAART and achieved HBs antigen (Ag)/antibody (Ab) seroconversion.

\section{Case Report}

A 18-year-old Japanese man was diagnosed with HIV infection and referred to our hospital. His risk factor was MSM (men who have sex with men), and he had had sexual relations with a large number of men from the general public starting at the age of 16 years. At the first medical examination, his HIV-ribonucleic acid (RNA) load was 46,000 copies/mL, and his CD4-positive cell count was $339 / \mu \mathrm{L}$. HBV co-infection was also diagnosed. $\mathrm{HBeAg}$ was positive, $\mathrm{HBeAb}$ was negative, and HBV viral load was more than

${ }^{1}$ Department of Gastroenterology and Metabology, Ehime University Graduate School of Medicine, Japan and ${ }^{2}$ Postgraduate Clinical Training Center, Ehime University Graduate School of Medicine, Japan

Received for publication November 14, 2013; Accepted for publication December 26, 2013

Correspondence to Dr. Yoichi Hiasa, hiasa@m.ehime-u.ac.jp 
Table. Laboratory Data before Starting Treatment

\begin{tabular}{|c|c|c|c|c|c|}
\hline Blood cells & & Blood chemis & & Serological test & \\
\hline $\mathrm{RBC}$ & $4.6 \times 10^{6} / \mu \mathrm{L}$ & AST & $27 \mathrm{U} / \mathrm{L}$ & HBs antigen & Positive \\
\hline Hemoglobin & $13.4 \mathrm{~g} / \mathrm{dL}$ & ALT & $22 \mathrm{U} / \mathrm{L}$ & HBs antibody & Negative \\
\hline Hematocrit & $39.4 \%$ & $\mathrm{LDH}$ & $189 \mathrm{U} / \mathrm{L}$ & HBe antigen & Positive \\
\hline WBC & $5,200 / \mu \mathrm{L}$ & ALP & $147 \mathrm{U} / \mathrm{L}$ & HBe antibody & Negative \\
\hline Neutrophil & $48 \%$ & $\gamma$-GTP & $13 \mathrm{U} / \mathrm{L}$ & $\begin{array}{l}\text { HBs antigen } \\
\text { (quantitative) }\end{array}$ & $388,000 \mathrm{IU} / \mathrm{mL}$ \\
\hline Lymphocyte & $40 \%$ & BUN & $13 \mathrm{mg} / \mathrm{dL}$ & HBV DNA & $8.8<\log$ copies $/ \mathrm{mL}$ \\
\hline Monocyte & $7.0 \%$ & Creatinine & $1.02 \mathrm{mg} / \mathrm{dL}$ & HBV genotype & A \\
\hline Eosinophil & $3.0 \%$ & Total protein & $8.0 \mathrm{~g} / \mathrm{dL}$ & & \\
\hline Basophil & $0 \%$ & Albumin & $3.9 \mathrm{~g} / \mathrm{dL}$ & HIV-1 RNA & 46,000 copies $/ \mathrm{mL}$ \\
\hline Platelet & $19.4 \times 10^{4} / \mu \mathrm{L}$ & & & CD4 positive cells & $228 / \mu \mathrm{L}$ \\
\hline
\end{tabular}

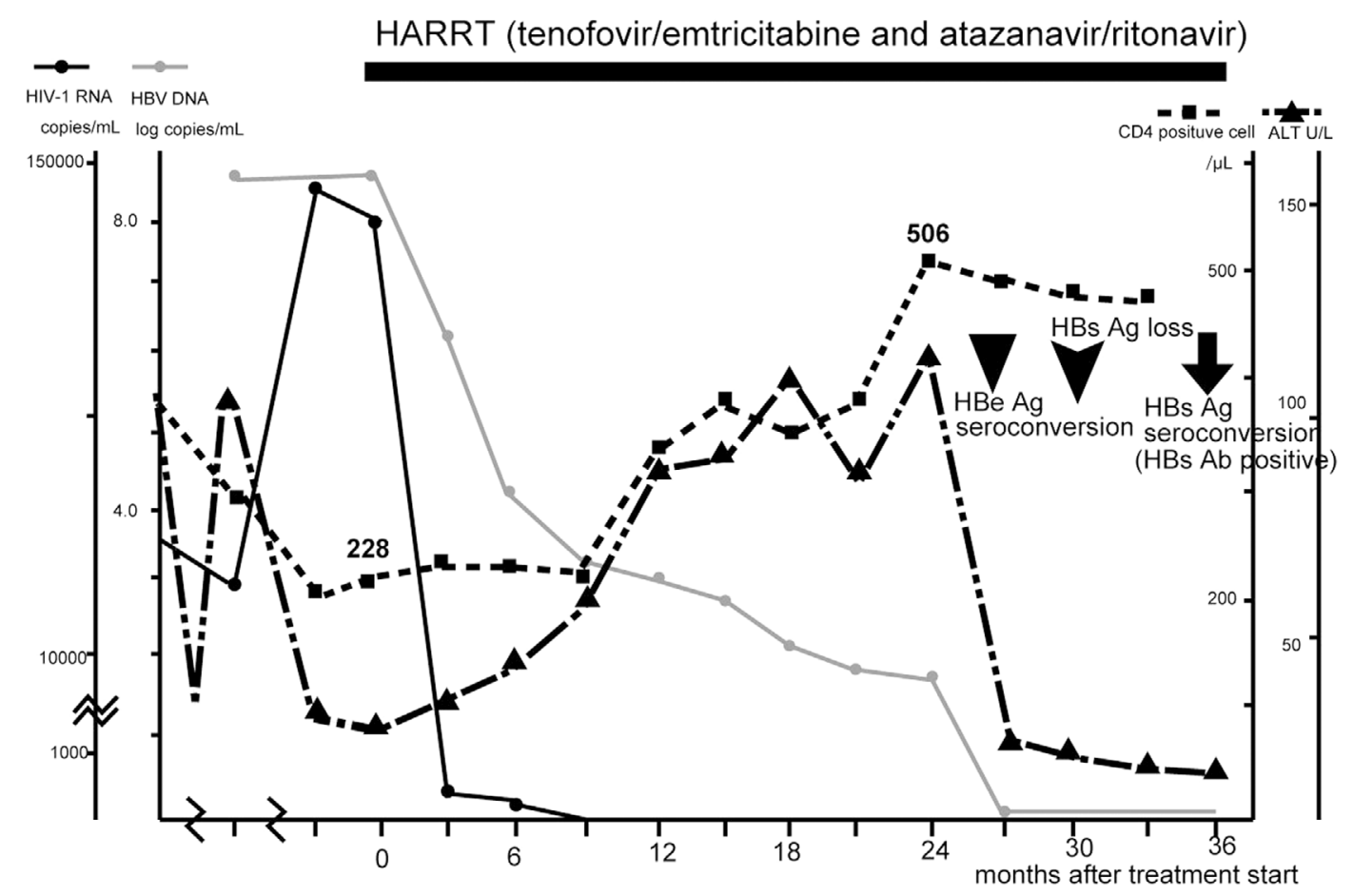

Figure. The clinical course of our case. HIV-RNA, HBV-DNA, number of CD4-positive cells, and levels of ALT are shown.

$8.8 \log$ copies/mL. Aspartate aminotransferase (AST)/alanine aminotransferase (ALT) were 56/105 U/L. His CD4 positive cell count decreased gradually to $220 / \mu \mathrm{L}$ by 1 year later. The AST/ALT level increased or decreased modestly according to its natural course. Two years after the first medical examination, he was admitted to our hospital to start HAART. The laboratory data upon admission is summarized in Table. He had neither a fever nor any symptoms suggesting acute infection. Cultures, serological tests and imaging did not reveal any signs of opportunistic infection. Drug resistance to anti-HIV drugs was not detected. TDF-based HAART [TDF/emtricitabine (FTC) and atazanavir (ATZ)/ ritonavir (RTZ)] was then started. HIV-RNA decreased rapidly over the following month to 680 copies $/ \mathrm{mL}$, and 12 months later, HIV-RNA was not detected. The CD4 positive cell count increased slowly to $400 / \mu \mathrm{L}$ after 1 year and to $500 / \mu \mathrm{L}$ after 2 years (Figure). The amount of HBVdeoxyribonucleic acid (DNA) decreased gradually after the HIV-RNA had decreased (Figure). The HBV viral load was $3.1 \log$ copies $/ \mathrm{mL}$ at 1 year and $<2.1 \log$ copies $/ \mathrm{mL}$ at 2 years after starting treatment. Viral breakthrough was not seen. At 26 months after starting treatment, $\mathrm{HBeAg} / \mathrm{Ab}$ seroconversion was evident. Moreover, $\mathrm{HBsAg}$ was not detected at 30 months, while $\mathrm{HBsAg} / \mathrm{Ab}$ seroconversion was detected at 36 months after starting treatment. Liver functional tests improved along with the decrease in HBV-DNA. The overview of the treatment course for this patient is shown in Figure. 


\section{Discussion}

Some drugs with anti-HBV activity, including interferon$\alpha$, pegylated interferon- $\alpha$, lamivudine, adefovir, entecavir (ETV), telbivudine, TDF and FTC in combination with TDF, are available to treat HIV patients with chronic hepatitis B (6). Both lamivudine and ETV (7) have been associated with the development of mutations in the HIV-reverse transcriptase, so they should not be used for the first-line treatment of HBV and HIV co-infected individuals without HAART. Long-term lamivudine use as monotherapy of chronic hepatitis B infection can also induce viral resistance, as conferred by a mutation in the tyrosine-methionineaspartate-aspartate motif (YMDD; rtM204V/I) of the HBV polymerase gene (8). The presence of the YMDD mutation has been reported in 14-32\% of patients who were not immunocompromised after 1 year and in $69 \%$ of patients after 5 years on lamivudine monotherapy (9). The emergence of viral resistance to lamivudine is more rapid and occurs more frequently in patients with HBV-HIV co-infection; the YMDD mutation was present in 50\% of such patients after 2 years and in $90 \%$ of patients after 4 years (10).

TDF is an NRTI approved for use within combination antiviral treatment for HIV patients. The overall proportion of patients achieving suppression of HBV replication was $57.4 \%, 79.0 \%$, and $85.6 \%$ at 1,2 , and 3 years, respectively (11). In addition to the high rate of virological suppression, TDF-resistance mutations, such as the combination of $\mathrm{rtL} 180 \mathrm{M}$, rtM204V/I, and $\mathrm{rtA} 194 \mathrm{~T}$ or N236T with A181A $(12,13)$, are rare (14). Therefore, TDF is often used as the NRTI backbone within HAART. On the other hand, for the treatment of HBV, ETV can be used as a first-line nucleotide analogue. However, ETV is not recommended for use in HBV patients co-infected with HIV because ETV can induce the resistant mutation of HIV against HAART (7).

Several studies have described the HBsAg loss rate in response to TDF-based HAART. For example, Matthews et al. reported that $8 \%$ of patients achieved HBsAg loss (15), and Theodora et al. reported that $12 \%$ of patients achieved HBsAg loss in response to TDF-based HAART (16). However, the $\mathrm{HBs} A g / \mathrm{Ab}$ seroconversion rate has not been fully delineated. HBsAg/Ab seroconversion is indicative of control of HBV and development of immunity; patients who experience $\mathrm{HBs} \mathrm{Ag} / \mathrm{Ab}$ seroconversion will not have further virologic, biochemical or histological evidence of active HBV infection or disease. In a study by Kosi et al., cumulative HBsAg loss was seen in $22 \%$ of patients, while HBs seroconversion was seen in only $3 \%$ of patients (17). These results suggest that HBs antibody generation was difficult to induce due to the immunodeficiency associated with HIV infection. In fact, more CD4-positive cells were found in HBsAb-positive patients than in HBsAb-negative patients before treatment (18).

In our case, $\mathrm{HBsAg} / \mathrm{Ab}$ seroconversion was seen 3 years after the start of treatment. The reason for the achievement of $\mathrm{HBsAg} / \mathrm{Ab}$ seroconversion needs to be investigated. Kosi et al. reported that an effective suppression of HBV replication is more important than host factors for achieving serologic response, and that this effect was not influenced by the CD4-positive cell count because $\mathrm{HBeAg}$ seroconversion and HBsAg loss were seen, even if the CD4-positive cell count was $<200 / \mu \mathrm{L}$. In our case, HBV viral load successfully decreased to $<2.1 \log$ copies/mL of HBV-DNA at 2 years after starting treatment. Patients co-infected with HBV and HIV tend to have lower transaminase elevation (3), and patients with HBsAg loss had higher baseline AST/ALT levels than patients without HBsAg loss (17). In our case, AST/ALT at baseline was slightly elevated. In previous studies of the effects of TDF-based HAART in patients with HBV-HIV coinfection, patients were older than 30 years (15-17). The shorter duration of HBV carriage or the younger age in the present case might have played a role in the successful treatment effect. Differences in HBV genotype might also influence the treatment effects. In some reports, the viral response to interferon therapy was favorable for HBV genotype A $(19,20)$. The present case was also HBV genotype A, so restoration of immune activity after HAART could have been one factor contributing to successful treatment. Moreover, according to recent reports, human leukocyte antigen (HLA)-DP polymorphism might influence HBV clearance (21). These factors might have contributed to HBsAg/ $\mathrm{Ab}$ seroconversion; however, additional investigation is needed to identify both the factors and the mechanisms of $\mathrm{HBsAg} / \mathrm{Ab}$ seroconversion in response to TDF-based HARRT.

Sixty-five percent of patients co-infected with HIV and HBV have HBV genotype A (22), as was the case with the present patient. HBV genotype A is more frequently associated with chronic infection (occurring in 10-15\% of those with acute infection) when compared with other genotypes (23). More than half of patients with acute hepatitis B due to horizontal infection are HBV genotype A (24), suggesting that it is important to avoid HBV genotype A infection as a sexually transmitted disease. The number of patients with chronic hepatitis B due to HBV genotype A is likely to increase in the future. Especially in patients with HIV, the incidence of persistent infection with HBV will be relatively higher, and the progression of liver damage more rapid. For those patients, quick and certain treatment against HBV as well as HIV is needed, and TDF-based HAART might fulfill this role by reducing HBV-DNA and HIV-RNA and inducing $\mathrm{HBsAg} / \mathrm{Ab}$ seroconversion.

\section{The authors state that they have no Conflict of Interest (COI).}

\section{References}

1. Alter MJ. Epidemiology of viral hepatitis and HIV co-infection. J Hepatol 44: S6-S9, 2006.

2. Weber R, Sabin CA, Friis-Møller N, et al. Liver-related deaths in persons infected with the human immunodeficiency virus: the 
D:A:D study. Arch Intern Med 166: 1632-1641, 2006.

3. Colin JF, Cazals-Hatem D, Loriot MA, et al. Influence of human immunodeficiency virus infection on chronic hepatitis B in homosexual men. Hepatology 4: 1306-1310, 1999.

4. Hoffman CJ, Seaberg EC, Young S, et al. Hepatitis B and longterm HIV outcomes in coinfected HARRT recipients. AIDS 23: 1881-1889, 2009.

5. Nikolopoulos GK, Paraskevis D, Hatzitheodorou E, et al. Impact of hepatitis B virus infection on the progression of AIDS and mortality in HIV-infected individuals: a cohort study and metaanalysis. Clin Infect Dis 48: 1763-1771, 2009.

6. Soriano V, Puoti M, Peters M, et al. Care of HIV patients with chronic hepatitis B: updated recommendations from the HIVHepatitis B Virus International Panel. AIDS 22: 1399-1410, 2008.

7. McMahon MA, Jilek BL, Brennan TP, et al. The HBV drug entecavir: effects on HIV-1 replication and resistance. N Eng J Med 356: 2614-2621, 2007.

8. Tripples GA, Ma MM, Fischer KP, et al. Mutations in HBV RNAdependent DNA polymerase confers resistance to lamibudine in vivo. Hepatology 24: 714-717, 1996.

9. Conjeevaram HS, Lok AS. Management of chronic hepatitis B. J Hepatol 38: S90-S103, 2003.

10. Benhamou $Y$, Bochet $M$, Thibault V, et al. Long-term incidence of hepatitis B virus resistance to lamivudine in human immunodeficiency virus-infected patients. Hepatology 30: 1302-1306, 1999.

11. Price H, Dunn D, Pillay D, et al. Suppression of HBV by tenofovir in HBV/HIV coinfected patients: a systemic review and meta-analysis. PLoS One 8: e68152, 2013.

12. Sheldon J, Camino N, Rodes B, et al. Selection of hepatitis B virus polymerase mutations in HIV-coinfected patients treated with tenofovir. Antivir Ther 10: 727-734, 2005.

13. Qi X, Xiong S, Yang H, et al. In vitro susceptibility of adefovirassociated hepatitis B virus polymerase mutations to other antiviral agents. Antivir Ther 12: 355-362, 2007.

14. Amini-Bavir-Olyaee S, Herbers U, Sheldon J, Luedde T, Trautwein C, Tacke F. The rtA194T polymerase mutation impacts viral replication and susceptibility to tenofovir in hepatitis B e antigen- positive and hepatitis $\mathrm{B}$ e antigen-negative hepatitis $\mathrm{B}$ virus strains. Hepatology 49: 1158-1165, 2009.

15. Matthews GV, Avihingsanon A, Lewin SR, et al. A randomized trial of combination hepatitis B therapy in HIV/HBV coinfected antiretroviral naïve individuals in Thailand. Hepatology 48: 10621069, 2008.

16. de Vries-Sluijs TE, Reijnders JG, Hansen BE, et al. Long-term therapy with tenofovir is effective for patients co-infected with human immunodeficiency virus and hepatis B virus. Gastroenterology 139: 1934-1941, 2010.

17. Kosi L, Reiberger T, Payer BA, et al. Five-year on-treatment efficacy of lamivudine-, tenofovir- and tenofovir + emtricitabinebased HARRT in HBV-HIV-coinfected patients. J Viral Hepat 19: 801-810, 2012.

18. Gatanaga H, Yasuoka A, Kikuchi Y, et al. Influence of prior HIV-1 infection on the development of chronic hepatitis B infection. Eur J Clin Microbiol Infect Dis 19: 237-239, 2000.

19. Erhardt A, Reineke U, Blondin D, et al. Mutations of the core promoter and response to interferon treatment in chronic replicative hepatitis B. Hepatology 31: 716-725, 2000.

20. Janssen HLA, van Zonneveld M, Senturk $H$, et al. Pegylated interferon alfa- $2 b$ alone or in combination with lamivudine for HBeAg-positive chronic hepatitis B: a randomized trial. Lancet 365: 123-129, 2005.

21. Nishida N, Sawai H, Matsuura K, et al. Genome-wide association study confirming association of HLA-DP with protection against chronic hepatitis B and viral clearance in Japanese and Korean. PLoS One 7: e39175, 2012.

22. Koibuchi T, Hitani A, Nakamura T, et al. Predominant of genotype A HBV in an HBV-HIV-1 dually positive population compared with an HIV-1-negative counterpart in Japan. J Med Virol 64: 435-440, 2001.

23. Sugauchi F, Orito E, Ohno T, et al. Spatial and chronological differences in hepatitis B virus genotypes from patients with acute hepatitis B in Japan. Hepatol Res 36: 107-114, 2006.

24. Yano K, Tamada Y, Yatsuhashi H, et al. Dynamic epidemiology of acute viral hepatitis in Japan. Intervirology 53: 70-75, 2010.

(C) 2014 The Japanese Society of Internal Medicine http://www.naika.or.jp/imonline/index.html 